\title{
Mercuric acetate-mediated annulation of homopropargylic alcohols having thioether substituent. A general route for the synthesis of tetrasubstituted furans from propargylic dithioacetals
}

\author{
Chih-Wei Chen, Tien-Yau Luh * \\ Department of Chemistry, National Taiwan University, Taipei 106, Taiwan
}

\section{A R T I C L E I N F O}

\section{Article history:}

Received 17 January 2009

Revised 5 February 2009

Accepted 5 February 2009

Available online 10 February 2009

\begin{abstract}
A B S T R A C T
Treatment of an alkyl-substituted propargylic dithioacetal with ${ }^{n} \mathrm{BuLi}$ followed by an aldehyde furnishes thio-substituted homopropargylic alcohol 7 which undergoes annulation in the presence of two equivalents of mercury acetate to give the corresponding mercurio-substituted furan $\mathbf{1 2}$. Reaction of 12 with iodine gives iodofuran in moderate to good yield.
\end{abstract}

(C) 2009 Elsevier Ltd. All rights reserved.
There is an ever burgeoning interest in furan derivatives because they are widely found in natural products, ${ }^{1}$ pharmaceuticals, ${ }^{2}$ flavors, ${ }^{3}$ and, more recently, materials applications. ${ }^{4}$ Numerous annulation protocols are known for the constructions of this useful heterocycle..$^{5-13}$ In particular, cyclizations involving allenyl, ${ }^{6-8}$ propargylic, $^{7-9}$ or homoallylic ${ }^{10}$ substrates have provided versatile entries for the synthesis of polysubstituted furans. We recently found that aryl-substituted propargylic dithiolanes $\mathbf{1}$ can be regioselectively transformed into tri- and tetra-substituted furans 3 and 4 (Eq. 1). ${ }^{7,8}$ The key to the success of this reaction lies on the regioselective formation of the allenyl methanol intermediate $\mathbf{2}$ which undergoes cyclization leading to furans. The process has been specifically useful for the synthesis of a range of alternating benzene-furan oligomers ${ }^{7,8}$ and substituted allenes. ${ }^{14}$ To our surprise, the regioselectivity is completely different when the propargylic dithioacetals contain only alkyl substituents (e.g., 5). Thus, selective olefinations of such dithioacetals giving $\mathbf{8}$ were recently uncovered (Eq. 2). ${ }^{15}$ In this regard, homopropargylic alcohol intermediates $\mathbf{7}$ are formed exclusively. Cyclizations of homopropargylic alcohols under various conditions are known to give the corresponding furan derivatives. ${ }^{11}$ It is worthy to mention that the presence of an appropriate leaving group such as hydroxy$1,{ }^{11 \mathrm{a}, \mathrm{l}-\mathrm{p}}$ alkoxyl, ${ }^{11 \mathrm{e}}$ or alkylidene group ${ }^{11 \mathrm{i}-\mathrm{k}}$ in homopropargylic alcohols appeared to be essential to facilitate such annulation procedure. As can be seen from Eq. 2, 7 contains a thioether substituent at the propargylic position which might be facilely eliminated under various conditions. It is therefore envisaged that annulation of homopropargylic alcohol $\mathbf{7}$ might provide a useful route for the synthesis of substituted furans with different regioselectivities as that described in Eq. 1. We now wish to report a selec-

\footnotetext{
* Corresponding author. Tel.: +886 22363 6288; fax: +88622364 4971.

E-mail address: tyluh@ntu.edu.tw (T.-Y. Luh).
}

tive synthesis of tetra-substituted furans from $\mathbf{5}$ having aliphatic substituents.
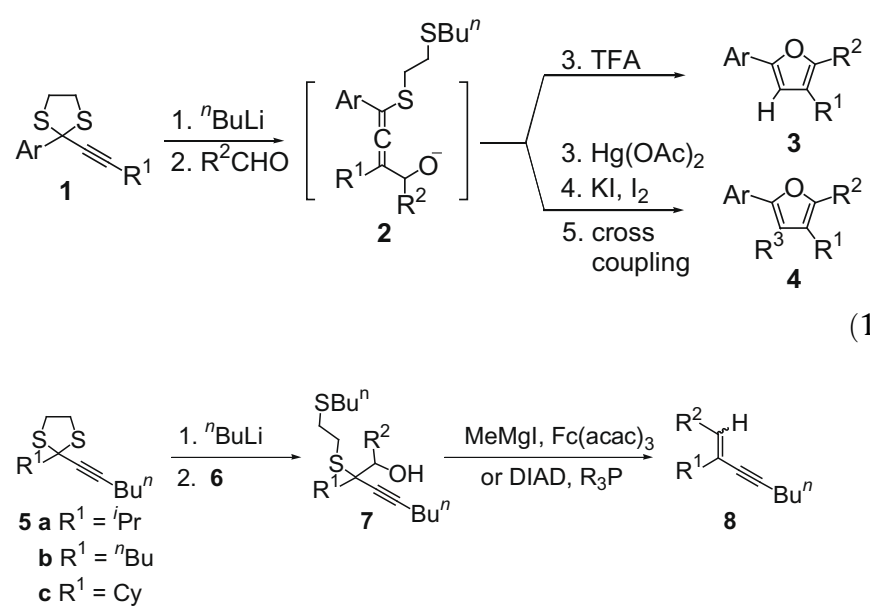

$\mathrm{R}^{2} \mathrm{CHO} \quad 6$ a $\mathrm{R}^{2}=\mathrm{Ph} ; \mathbf{b} \mathrm{R}^{2}={ }^{n} \mathrm{Bu} ; \mathbf{c} \mathrm{R}^{2}={ }^{t} \mathrm{Bu} ; \mathbf{d} \mathrm{R}^{2}=$ Mesityl; e $\mathrm{R}^{2}=1-\mathrm{Naph} ;$ $f \mathrm{R}^{2}=4-\mathrm{MeOC}_{6} \mathrm{H}_{4} ; \mathbf{g ~ R} \mathrm{R}^{2}=4-\mathrm{BrC}_{6} \mathrm{H}_{4} ; \mathbf{h} \mathrm{R}^{2}=4-\mathrm{Bu}^{t} \mathrm{O}_{2} \mathrm{CC}_{6} \mathrm{H}_{4}$; i R $\mathrm{R}^{2}=\mathrm{p}-\mathrm{NCC}_{6} \mathrm{H}_{4}$

In the beginning of this research, a range of different conditions were employed to scrutinize the annulation conditions. As cyclization of $\mathbf{2}$ can readily be promoted by acids, ${ }^{7,8}$ different kinds of Lewis acid conditions were employed. Whilst TFA is successful to mediate annulation of allenylmethanols, no reaction was found when 7a was treated under the same conditions. Silver (I) has been 
Table 1

Synthesis iodofurans $\mathbf{9}$ from propargylic dithioacetals $\mathbf{5}$ and aldehydes $\mathbf{6}$

\begin{tabular}{|c|c|c|c|c|c|c|}
\hline Entry & Substrate $\mathbf{5}$ & $\mathrm{R}^{1}$ & $\mathrm{R}^{2}$ & $\mathrm{R}^{3}$ & Yield of $\mathbf{7}(\mathrm{dr})^{\mathrm{a}}$ & Yield of $\mathbf{9}$ \\
\hline 1 & $5 a$ & ${ }^{i} \mathrm{Pr}$ & ${ }^{n} \mathrm{Bu}$ & $\mathrm{Ph}$ & a $74(2.3 / 1)$ & a 67 \\
\hline 2 & & & & ${ }^{n} \mathrm{Bu}$ & c $72^{\mathrm{b}}$ & c 54 \\
\hline 3 & & & & ${ }^{t} \mathrm{Bu}$ & d $54(4.4 / 1)$ & d 62 \\
\hline 4 & & & & Mesityl & e $51(1.1 / 1)$ & e 80 \\
\hline 5 & & & & 1-Naphthyl & f $87(4.2 / 1)$ & f 54 \\
\hline 6 & & & & $p-\mathrm{MeOC}_{6} \mathrm{H}_{4}$ & g $80(6.4 / 1)$ & g 77 \\
\hline 7 & & & & $p-\mathrm{BrC}_{6} \mathrm{H}_{4}$ & h $56(5.4 / 1)$ & h 47 \\
\hline 8 & $5 \mathbf{b}$ & ${ }^{n} \mathrm{Bu}$ & ${ }^{n} \mathrm{Bu}$ & $\mathrm{Ph}$ & i $73(3.8 / 1)$ & i 46 \\
\hline 9 & & & & $p-\mathrm{Bu}^{t} \mathrm{O}_{2} \mathrm{CC}_{6} \mathrm{H}_{4}$ & j $37(1.7 / 1)$ & j 42 \\
\hline 10 & & & & $p-\mathrm{NC} \mathrm{C}_{6} \mathrm{H}_{4}$ & k $83(1.6 / 1)$ & k 43 \\
\hline 11 & $5 c$ & ${ }^{c}$ Hex & ${ }^{n} \mathrm{Bu}$ & $\mathrm{Ph}$ & $169(4.8 / 1)$ & 155 \\
\hline
\end{tabular}

a Diastereomeric ratios (dr) were determined by ${ }^{1} \mathrm{H}$ NMR.

b Diastereomeric ratio was not determined.<smiles>[R]Oc1c(Br)oc([R])c1[R]</smiles>

Scheme 1.

extensively employed for the annulation of alkynyl-substituted ethylene glycols ${ }^{11 \mathrm{~m}}$ or homopropargylic alcohols having vinylidene moiety to yield furans. ${ }^{11 \mathrm{i}, \mathrm{k}}$ However, treatment of 7a under these conditions gave at most trace amount of the desired furans. Gold (III) catalyst ${ }^{7 \mathrm{~b}, \mathrm{~d}-\mathrm{g}}$ was unable to promote the reaction of $\mathbf{7 a}$, and $\mathrm{ICl}^{8 \mathrm{e}, 11} \mathrm{n}$ led to decomposition of the starting materials with no desired annulation product. We recently found the allenyl methanol derivatives $\mathbf{2}$ underwent ring closure reaction giving tetra-substituted furans $\mathbf{4}$ upon treatment with mercuric acetate followed by iodine. $^{8 \mathrm{e}}$ Since the mercuric species is very thiophilic, the sulfur moiety in $\mathbf{2}$ is facilely eliminated. It is therefore envisaged that reaction of 7a under similar conditions might also afford the corresponding tetrasubstituted furans $\mathbf{9}$ with different regioselectivities as those shown in Eq. 1.

Compound 7a was treated with 2 equiv of mercuric acetate at room temperature for $12 \mathrm{~h}$. The reaction mixture was then allowed to react with three equiv each of iodine and $\mathrm{KI}$ for $3 \mathrm{~h}$ to furnish the corresponding furan 9a in 61\% yield. The yield of 9a was improved to $67 \%$ when the cyclization reaction time was $18 \mathrm{~h}$.

Reactions of 5 with 1.1 equiv of BuLi in THF at $-78{ }^{\circ} \mathrm{C}$ for $1 \mathrm{~h}$ followed by addition of 1 equiv of aldehyde $\mathbf{6}$ gave a diastereomeric mixture of homopropargylic alcohols $\mathbf{7} .{ }^{16}$ Compound $\mathbf{7}$ was treated with 2 equiv of mercuric acetate for $18 \mathrm{~h}$ and the mixture was allowed to react with 3 equiv each of iodine and KI to give $\mathbf{9}$ in moderate to good yield. ${ }^{17}$ Representative results are outlined in. Table 1. Although the mechanism for the annulation of $\mathbf{7}$ has not been established, oxymercuration at the triple bond may lead to $\mathbf{1 1}$ followed by elimination of the sulfur moiety to afford $\mathbf{1 2}$ (Scheme 1).<smiles>[R]c1oc(Br)c(I)c1[R]</smiles>

As can be see from Table 1, methoxy, halogen, ester, or cyano groups on aldehyde $\mathbf{6}$ (entries $6,7,9$, and 10) could be used and the corresponding furans 9 remained intact in both nucleophilic addition and ring closure steps. Even sterically hindered group on dithiolane moiety (e.g., entry 11) or on aldehyde 6 (entries 4 and 5) was obtained in satisfactory yield. In order to assure the regioselective formation of homopropargylic alcohols $7, \mathrm{R}^{1}$ and $\mathrm{R}^{2}$ had to be aliphatic. In other words, when $\mathrm{R}^{1}$ was an aryl group, $\mathbf{2}$ was the only product from the reaction. On the other hand, when $\mathrm{R}^{2}$ was phenyl, a mixture of regioisomers $\mathbf{2}$ and $\mathbf{7}$ was obtained.

Although the origin of the regioselectivity of the nucleophilic addition of the anion derived from 5 to aldehyde $\mathbf{6}$ remained to be clarified, the overall reaction; however, does provide a convenient synthesis of substituted furans $\mathbf{9}$ from the corresponding alkyl-substituted propargylic dithioacetals $\mathbf{5}$. The iodine substituent in 9 can be easily displaced by different kinds of coupling reactions. $^{8 \mathrm{e}}$ In addition, metal-halogen exchange process can also be used for further carbon-carbon bond formation. ${ }^{8 \mathrm{e}}$ Tin hydride reduction of the carbon-iodine bond can lead to trisubstituted furans. The present results complement our previous works ${ }^{8}$ for the synthesis of polysubstituted furans with different regioselectivities.

\section{Acknowledgment}

We thank the National Science Council and the National Taiwan University of the Republic of China for financial support.

\section{Supplementary data}

Experimental details for the preparation of 5, 7 and $\mathbf{9}$ and ${ }^{1} \mathrm{H}$ NMR spectra of $\mathbf{9}$. Supplementary data associated with this article can be found, in the online version, at doi:10.1016/ j.tetlet.2009.02.043.

\section{References and notes}

1. (a)For reviews, see: Comprehensive Heterocyclic Chemistry; Katrizky, A. R., Rees, C. W., Scriven, E. F. V., Eds.; Pergamon: New York, 1996; Vol. 2, (b)Comprehensive Heterocyclic Chemistry; Katrizky, A. R., Rees, C. W., Eds.; Pergamon: New York, 1984; Vol. 4, (c)Natural Products Chemistry; Nakanishi, K., Goto, T., Ito, S., Natori, S., Nozoe, S., Eds.; Kodansha: Tokyo, 1974; Vols. 1-3, (d) Shipman, M. Contemp. Org. Synth. 1995, 2, 1. 
2. (a)For reviews, see: Eicher, T., Hauptmann, S., Eds.The Chemistry of Heterocycles: Structure, Reactions, Syntheses, and Applications; Wiley-VCH: Weinheim, 2003; (b)Common Fragrance and Flavor Materials; Bauer, K., Garbe, D., Eds.; VCH: Weinheim, 1985; (c) Vernin, G. The Chemistry of Heterocyclic Flavouring and Aroma Compounds; Ellis Horwood: Chichester, 1982.

3. For reviews, see: (a) Maier, M. In Organic Synthesis Highlights II; Waldmann, H., Ed.; VCH: Weinheim, 1995; p 231; (b)Comprehensive Organic Synthesis; Trost, B. M., Fleming, I., Eds.; Pergamon Press: Oxford, 1991; (c) Lipshutz, B. H. Chem. Rev. 1986, 86, 795

4. (a) Zhang, L.-Z.; Chen, C.-W.; Lee, C.-F.; Wu, C.-C.; Luh, T.-Y. Chem. Commun. 2002, 2336; (b) Wu, C.-C.; Hung, W.-Y.; Liu, T.-L.; Zhang, L.-Z.; Luh, T.-Y. J. Appl. Phys. 2003, 93, 5465; (c) Lin, S.-Y.; Chen, I.-W. P.; Chen, C.-H.; Lee, C.-F.; Chou, C.-M.; Luh, T.-Y. J. Phys. Chem. B 2005, 109, 7915; (d) Tsuji, H.; Mitsui, C.; Ilies, L.; Sato, Y.; Nakamura, E. J. Am. Chem. Soc. 2007, 129, 11902; (f) Chen, I.-W. P.; Fu, M.-D.; Tseng, W.-H.; Chen, C.-H.; Chou, C.-M.; Luh, T.-Y. Chem. Commun. 2007, 3074.

5. For recent reviews, see: (a) Hou, X. L.; Cheung, H. Y.; Hon, T. Y.; Kwan, P. L.; Lo, T. H.; Tong, S. Y.; Wong, H. N. C. Tetrahedron 1998, 54, 1955; (b) Keay, B. A Chem. Soc. Rev. 1999, 28, 209; (c) Hou, X.-L.; Yang, Z.; Wong, H. N. C. Prog. Heterocycl. Chem. 2001, 13, 130.

6. (a) Marshall, J. A.; Robinson, E. D. J. Org. Chem. 1990, 55, 3450; (b) Marshall, J. A.; Wang, X. J. Org. Chem. 1991, 56, 960; (c) Marshall, J. A.; Bartley, G. S. J. Org. Chem. 1994, 59, 7169; (d) Marshall, J. A.; Wallace, E. M. J. Org. Chem. 1995, 60 796.

7. (a) Ma, S.; Li, L. Org. Lett. 2000, 2, 941; (b) Hashmi, A. S. K.; Schwarz, L.; Choi, J.H.; Frost, T. M. Angew. Chem. Int. Ed. 2000, 39, 2285; (c) Kel'in, A. V.; Gevorgyan, V. J. Org. Chem. 2002, 67, 95; (d) Ma, S.; Zhang, J.; Lu, L. Chem. Eur. J. 2003, 9, 2447-2456; (e) Sromek, A. W.; Rubina, M.; Gevorgyan, V. J. Am. Chem. Soc. 2005, 127, 10500; (f) Schwier, T.; Sromek, A. W.; Yap, D. M. L.; Chernyak, D.; Gevorgyan, V. J. Am. Chem. Soc. 2007, 129, 9868; (g) Dudnik, A. S.; Sromek, A. W.; Rubina, M.; Kim, J. T.; Kel'in, A. V.; Gevorgyan, V.J. Am. Chem. Soc. 2008, 130, 1440 .

8. (a) Lee, C.-F.; Yang, L.-M.; Hwu, T.-Y.; Feng, A.-H.; Tseng, J.-C.; Luh, T.-Y. J. Am. Chem. Soc. 2000, 122, 4992; (b) Lee, C.-F.; Liu, C.-Y.; Song, H.-C.; Luo, S.-J.; Tseng J.-C.; Tso, H.-H.; Luh, T.-Y. Chem. Commun. 2002, 2824-2825; (c) Liu, C-Y.; Luh, T.-Y. Org. Lett. 2002, 4, 4305-4307; (d) Tseng, J.-C.; Lin, H.-C.; Huang, S.-L.; Lin, C.-L.; Jin, B.-Y.; Chen, C.-Y.; Yu, J.-K.; Chou, P.-T.; Luh, T.-Y. Org. Lett. 2003, 5 , 4381; (e) Tseng, J.-C.; Chen, J.-H.; Luh, T.-Y. Synlett 2006, 1209; (f) Chou, C.-M.; Chen, W.-Q.; Chen, J.-H.; Lin, C.-L.; Tseng, J.-C.; Lee, C.-F.; Luh, T.-Y. Chem. Asian J. 2006, 1, 46-55; (g) Lin, H.-C.; Lin, W.-Y.; Bai, H.-T.; Chen, J.-H.; Jin, B.-Y.; Luh, T.-Y. Angew. Chem., Int. Ed. 2007, 46, 897-900; (h) Lin, C.-L.; Chou, C.-M.; Luh, T.-Y. J. Org. Chem. 2007, 72, 8531-8534.

9. For reviews on the use of propargylic dithioacetals, see: (a) Luh, T.-Y. Pure Appl. Chem. 2005, 77, 1213; (b) Luh, T.-Y.; Lee, C.-F. Eur. J. Org. C 2005, 3839; (c) Luh, T.-Y.; Lin, H.-C.; Chou, C.-M. Pure Appl. Chem. 2008, 80, 475

10. (a) Marshall, J. A.; DuBay, W. J. J. Org. Chem. 1993, 58, 3435; (b) Kim, S.; Kim, Y. G. Synlett 1991, 869; (c) Fukuda, Y.; Shiragami, H.; Utimoto, K.; Nozaki, H. J. Org. Chem. 1991, 56, 5816

11. (a) Babudri, F.; Cicco, S. R.; Farinola, G. M.; Lopez, L. C.; Naso, F.; Pinto, V. Chem. Commun. 2007, 3756; (b) Fu, Z.; Wang, M.; Ma, Y.; Liu, Q.; Liu, J. J. Org. Chem 2008, 73, 7625.
12. (a) Venus-Danilova, E. D.; Al'bitskaya, V. M. Zh. Obshch. Khim. 1952, 22, 816; (b) Utimoto, K. Pure Appl. Chem. 1983, 55, 1845; (c) Sham, H. L.; Betebenner, D. A. J. Chem. Soc., Chem. Commun. 1991, 1134; (d) Tani, K.; Sato, Y.; Okamoto, S.; Sato, F. Tetrahedron Lett. 1993, 34, 4975; (e) Pasha, M. K.; Ahmad, F. Lipids 1993, 28, 1027; (f) Trost, B. M.; McIntosh, M. C. J. Am. Chem. Soc. 1995, 117, 7255; (g) Schmidt, B.; Kocienski, P.; Reid, G. Tetrahedron 1996, 52, 1617; (h) Stephen, A.; Hashmi, K.; Schwarz, L. Chem. Ber. 1997, 130, 1449; (i) Marshall, J. A.; Sehon, C. A. Org. Synth. 1999, 76, 263; (j) Qing, F.-L.; Gao, W.-Z.; Ying, J. J. Org. Chem. 2000, 65, 2003; (k) Zhang, D.; Yuan, C. Eur. J. Org. Chem. 2007, 3916; (1) Wen, S.-g.; Liu, W.-m.; Liang, Y.-m. Synthesis 2007, 3295; (m) Hayes, S. J.; Knight, D. W.; Menzies, M. D.; O'Halloran, M.; Tan, W.-F. Tetrahedron Lett. 2007, 48, 7709; (n) Bew, S. P.; El-Taeb, G. M. M.; Jones, S.; Knight, D. W.; Tan, W.-F. Eur. J. Org. Chem. 2007, 5759; (o) Arimitsu, S.; Jacobsen, J. M.; Hammond, G. B. J. Org. Chem. 2008, 73, 2886; (p) Yada, Y.; Miyake, Y.; Nishibayashi, Y. Organometallics 2008, 27, 3614 .

13. (a) Nishibayashi, Y.; Yoshikawa, M.; Inada, Y.; Milton, M. D.; Hidai, M.; Uemura, S. Angew. Chem., Int. Ed. 2003, 42, 2681; (b) Yin, G.; Wang, Z.; Chen, A.; Gao, M.; Wu, A.; Pan, Y. J. Org. Chem. 2008, 73, 3377.

14. (a) Tseng, H.-R.; Luh, T.-Y.J. Org. Chem. 1997, 62, 4568; (b) Tseng, H.-R.; Lee, C.F.; Yang, L.-M.; Luh, T.-Y. J. Org. Chem. 1999, 64, 8582.

15. (a) Huang, L.-F.; Chen, C.-W.; Luh, T.-Y. Org. Lett. 2007, 9, 3363; (b) Chen, C.-W.; Luh, T.-Y. J. Org. Chem. 2008, 73, 8357.

16. Typical procedure for the preparation of homopropargylic alcohol 7: At $-78{ }^{\circ} \mathrm{C}$, under $\mathrm{N}_{2}$ atmosphere, to a THF $(50 \mathrm{~mL})$ solution of $\mathbf{5 a}(1.14 \mathrm{~g}, 5 \mathrm{mmol})$ was added ${ }^{n} \mathrm{BuLi}(2.4 \mathrm{~mL}, 2.5 \mathrm{M}$ in hexane, $6 \mathrm{mmol}$ ) dropwise and the mixture was stirred for $1 \mathrm{~h}$. $p$-Anisaldehyde $\mathbf{6 f}(0.61 \mathrm{~mL}, 5 \mathrm{mmol})$ in THF $(10 \mathrm{~mL})$ was then added dropwise and the mixture was gradually warmed to $\mathrm{rt}$ and stirred for $8 \mathrm{~h}$, quenched with satd $\mathrm{NH}_{4} \mathrm{Cl}$, washed with brine, and extracted with ether. The organic layer was dried $\left(\mathrm{MgSO}_{4}\right)$, filtered, and the filtrate was evaporated in vacuo to give the residue which was chromatographed on silica gel (hexane/ ethyl acetate $=30 / 1)$ to give $7 \mathbf{f}(\mathrm{dr}$ ratio $=6.4 / 1)$ in $84 \%$ yield: major isomer: ${ }^{1} \mathrm{H}$ NMR $\left(\mathrm{CDCl}_{3}, 400 \mathrm{MHz}\right): \delta 0.92(\mathrm{t}, J=7.0 \mathrm{~Hz}, 3 \mathrm{H}), 0.94(\mathrm{t}, J=7.0 \mathrm{~Hz}, 3 \mathrm{H}), 1.11(\mathrm{~d}$, $J=6.5 \mathrm{~Hz}, 6 \mathrm{H}), 1.34-1.47(\mathrm{~m}, 4 \mathrm{H}), 1.48-1.58(\mathrm{~m}, 4 \mathrm{H}), 1.84$ (sept, $J=6.5 \mathrm{~Hz}, 1 \mathrm{H})$, $2.29(\mathrm{t}, J=7.0 \mathrm{~Hz}, 2 \mathrm{H}), 2.47(\mathrm{t}, J=7.4 \mathrm{~Hz}, 2 \mathrm{H}), 2.51-2.72(\mathrm{~m}, 4 \mathrm{H}), 3.04(\mathrm{~d}$, $J=6.0 \mathrm{~Hz}, 1 \mathrm{H}), 3.82(\mathrm{~s}, 3 \mathrm{H}), 4.74(\mathrm{~d}, J=6.0 \mathrm{~Hz}, 1 \mathrm{H}), 6.82-6.88(\mathrm{~m}, 2 \mathrm{H}), 7.42-$ $7.47(\mathrm{~m}, 2 \mathrm{H})$; characteristic ${ }^{1} \mathrm{H}$ NMR signals for the minor isomer: $\delta 3.90(\mathrm{~s}, 3 \mathrm{H})$, $4.78(\mathrm{~d}, J=4.8 \mathrm{~Hz}, 1 \mathrm{H})$.

17. Typical procedure for the preparation of 9: A mixture of $7 \mathbf{f}(167 \mathrm{mg}, 0.5 \mathrm{mmol})$ and $\mathrm{Hg}(\mathrm{OAc})_{2}(319 \mathrm{mg}, 1.0 \mathrm{mmol})$ in THF $(5 \mathrm{~mL})$ was stirred at $\mathrm{rt}$ for $18 \mathrm{~h}$. KI (249 $\mathrm{mg}, 1.5 \mathrm{mmol})$ and $\mathrm{I}_{2}(381 \mathrm{mg}, 1.5 \mathrm{mmol})$ were then added and the mixture was further stirred for $3 \mathrm{~h}$, quenched with satd $\mathrm{Na}_{2} \mathrm{~S}_{2} \mathrm{O}_{3}$, and extracted with ether. The organic layer was washed with $10 \% \mathrm{Na}_{2} \mathrm{~S} \cdot 9 \mathrm{H}_{2} \mathrm{O}$, dried $\left(\mathrm{MgSO}_{4}\right)$, filtered, and the filtrate was evaporated in vacuo to give the residue which was chromatographed (hexane/chloroform $=30 / 1$ ) on silica gel to give $\mathbf{9 f}$ as a colorless liquid (153 mg, 77\%): ${ }^{1} \mathrm{H}$ NMR $\left(\mathrm{CDCl}_{3}, 400 \mathrm{MHz}\right): \delta 0.97(\mathrm{t}, J=7.2 \mathrm{~Hz}$, $3 \mathrm{H}), 1.34(\mathrm{~d}, J=7.2 \mathrm{~Hz}, 6 \mathrm{H}), 1.36-1.48(\mathrm{~m}, 2 \mathrm{H}), 1.62-1.72(\mathrm{~m}, 2 \mathrm{H}), 2.72(\mathrm{t}$, $J=7.6 \mathrm{~Hz}, 2 \mathrm{H}$ ), 3.18 (sept, $J=7.2 \mathrm{~Hz}, 1 \mathrm{H}), 6.92-6.97(\mathrm{~m}, 2 \mathrm{H}), 7.36-7.41(\mathrm{~m}, 2 \mathrm{H})$; ${ }^{13} \mathrm{C}$ NMR $\left(100 \mathrm{MHz}, \mathrm{CDCl}_{3}\right): \delta 14.0,21.6,22.4,26.2,27.6,30.3,55.3,65.8,113.7$, $124.1,125.7,129.0,147.5,155.3,158.9$; HRMS (FAB) calcd for $\mathrm{C}_{18} \mathrm{H}_{23} \mathrm{O}_{2} \mathrm{I}$ : 398.0743, found: 398.0748 . 